\title{
Property Title, Formal Credit Access and Business Expansion
}

\author{
Emmanuel O. Okon ${ }^{1}$ \\ ${ }^{1}$ Department of Economics, Kogi State University, Anyigba, Kogi State, Nigeria \\ Correspondence: Department of Economics, Kogi State University, Anyigba, Kogi State, Nigeria, E-mail: \\ tonydom57@yahoo.com. Tel: +2348023275716
}

Received: January 2, 2018

Accepted: January 4, 2018

Online Published: January 12, 2018

\begin{abstract}
The cardinal objective of this study is to examine the impact of Land Title Document on credit access and business growth. A case study was applied on Nasarawa state, Nigeria to better understand the phenomenon been researched. Information was gathered from the field through face-to-face interviews and through the administering of questionnaire among business operators in some selected towns. The research revealed that a large proportion of respondents do not have Land Title Document to their business premises and that they have never made a request for it from government agency before. $60.00 \%$ of respondents' responded that the duration of the processing of the document takes months/years. $44.52 \%$ of respondents reported that never have banks made request for the document before granting loan facilities while $30.24 \%$ of respondents' indicated 'yes, often'. From the responses, $40.47 \%$ of respondents were of the view that possession of ' $\mathrm{C}$ of $\mathrm{O}$ ' document will not enhance their capital based and business expansion. The views of the respondents suggest that delay is a major problem in the processing of Land Title Document. Among the reasons cited for the delays are problems with documentation and legal issues. A reasonable percentage of respondents (31.43\%) were of the view that the cost of obtaining ' $\mathrm{C}$ of $\mathrm{C}$ ' is high and difficult in the State. A suggested solution is that the government agency handling this document should be reorganize and the steps required to obtain this document should be reduced and made uniform within the State.
\end{abstract}

Keywords: Land Title Document, Credit Access, Business Growth, Nasarawa State, Nigeria

\section{Introduction}

A business (also known as an enterprise, a company or a firm) is an organizational entity involved in the provision of goods and services to consumers(O'Sullivan and Sheffrin, 2003; Aaker and Mc Loughlin, 2010). According to Akrani (2011) business is an economic activity, which is related with continuous and regular production and distribution of goods and services for satisfying human wants. Therefore, business has become part and parcel of human existence in particular and global world in general. It has the characteristics of being involved in transfer or exchange of goods and services, as well as human activity directed towards the acquisition of wealth, which will lead to growth by increasing the national income. Apart from this, business has the aims and objectives of earning profit, manufacture goods and or render services to the society, involving payment of taxes regularly to generate income for the government, provide job opportunities for the public, improve the standard of living of everybody in the country thereby resulting in sustained growth or development (Satope and Akanbi, 2014).

Doing business in Nigeria is currently viewed as one of the most lucrative business ventures in today's global business environment. For the past 50 years, Nigeria has been dependent on its valuable oil resources which have brought great wealth to a selected (Viewmynaijanaira, 2015). However, as Nigeria's economic sphere slowly changes, its economic structure diversifies to overcome its dependency on oil. This shift has opened up the playing field for a new generation of entrepreneurs in Nigeria.

Pursuing business requires properties and properties cannot exist without land and whatever is permanently invested on land becomes part of the land. Its ownership and policies vary differently in countries and environments. In Nigeria, the law vests ownership of all land within a state (except those vested in the Federal Government or its agent) in the Governor of the state who holds land in trust for the people and allocate same as far as the urban area is 
concerned, to individuals and corporate entities for residential, commercial, agricultural and other purposes allowed by law (Olofinji, 2015).

However, there is a common knowledge that land registration determines accessibility to formal credit for investment and growth. Such a proposition is premised on the argument that land registration enables owners of registered landed property to use their property as collateral for loans from financial institutions. A sequel to these arguments are the assertions that: western nations are highly capitalized and developed due to the fact that they have comprehensive land registration systems; and high level of poverty and underdevelopment exits in third world countries because it is an infinitesimal proportion of landed property ownership that is registered, which it is argued, impedes the ability of owners to use their property as collateral to access formal capital for investment and wealth creation. Based on the preceding commonly held views, developing countries, backed by international donor institutions like the World Bank, have been religiously pursuing land registration policies and programs over the years (ERES, 2009). However, despite many years of the implementation of land registration programs, poverty and underdevelopment still exists in pandemic proportions in the third world. Considering Africa, for example, research conducted by the World Bank in 2007 shows that the region is a critical development priority since it has some of the world's poorest countries and during the past two decades, the number of poor people in the continent has doubled to 300 million, which is more than 40 percent of the continent's population (ERES, 2009). No fewer than 112million Nigerians now live below poverty level as global poor hits one billion mark (Ahiuma-Young, 2016).

The property title provided in Nigeria presents an interesting case for research and analysis. The main purpose of this study is to examine the extent to which Land Title Document impacts on access to credit for business investment and growth. This is because of the knowledge gap on whether enhancing property right through registration really promotes access to credit for investment. Existing research does not give consistent outcomes, research carried out in Latin America: Honduras, Paraguay and Brazil the results were positive (Feder and Nishio 1998). Whereas a study conducted in Africa: Ghana, Kenya and Rwanda shows that there was no clear impact on credit access (Migot-Adholla et al., 1991). There is a need for more empirical evidence to verify these arguments. A case study contributes to a better understanding of the phenomenon been researched by studying single example. In this present research, a case study was applied on Nasarawa state, Nigeria.

The preceding discourse sets the context of this paper. The next section surveys the conceptual framework and empirical evidence on the economics of land registration. Section three looks at business environment and land ownership in Nigeria. Section four describes the methodology as well as the study area and technique of analysis. Findings and discussions were presented in section five while summary, conclusion and recommendations were made in the last section.

2. Economics of Land Registration: Conceptual Framework and Empirical Evidence

The conceptual framework for economics of land registration was first developed in the context of a study on rural Thailand (Feder et al., 1988). Two sources of linkage between titles and economic performance are highlighted, namely the effect of titles in enhancing tenure security, and the role of titles in collateral arrangements, facilitating access to institutional credit. The productivity of land in any of its uses (whether agricultural or urban/commercial) is dependent on complementary investment in the form of drainage, structure, clearing of stones and trees, and other improvements. By their nature, these investments yield benefits over time, while the expense of cost and effort is borne up-front. The incentive to undertake these investments is thus affected significantly by the expectations regarding the length of the horizon over which the investor might reap the benefits. These expectations, in turn, depend on the risk of challenges to the investor's possession of the land, whether through ownership disputes, eviction, or expropriation by government. These risks are referred to commonly as "tenure insecurity". Registration systems and Land titles have emerged in mankind's history as an institutional arrangement to reduce such insecurity. With ownership officially documented and verified, the risk of challenges to ownership is reduced, and the likelihood of having to incur high costs in defending one's possession of land is lower, incentives to invest are enhanced, and land productivity is increased.

Credit transactions are inherently risky, as the lender provides cash in advance against a promise of repayment (with interest) over time. Lenders have typically less information than the borrower regarding the prospects of the loan being repaid in full and in a timely fashion, hence the emergence of collateral arrangements where fixed assets, most often land, are used as a guarantee for loan repayment. For land to serve as collateral, the lender must be assured that the borrower is indeed the owner, and thus a secure title is needed to mortgage land, especially when borrowing from formal lending institutions which often have imperfect information on the borrower. While borrowers without a secure title can borrow from informal lenders without using land as collateral, such informal credit is typically much more expensive than formal credit, usually small in amount, and mostly limited to short-term loans. 
Formal treatment of the link between property rights and credit supply is provided by Besley (1995) and Feder (1985). The principal argument is that formal property titles encourage lenders to use land as collateral by lowering the risk of collateral loss, the information costs involved in verifying ownership and the foreclosure costs under default, thereby reducing the effective leverage ratio and increasing the net collateral value of land. As discussed by Besley, in competitive markets with full information, improved access to collateral reduces the risk premium on lending and hence the interest rate borrowers face. Meanwhile, in the presence of information asymmetries, the use of collateral can eliminate credit rationing by reducing agency problems. However, early literature highlighted the effect of land titling on access to formal credit, since a land title is often a mandatory precondition for commercial or official bank loans (Wai, 1957; Sacay, 1973; Dorner and Saliba, 1983; Aku, 1986). Panandikar (1956) illustrated the interest payment savings realized through land registration, through an example of lenders charging 8 to $16 \%$ on secured loans compared with 18 to $37.5 \%$ on unsecured loans, in some parts of India. However, until the late 1980's, there was little quantitative analysis on the link between secure land tenure and the use of credit.

The impact of land registration on investment has also been discussed. Sales et al (1970) found that in Costa Rica, positive correlations (in the range of 0.40 to 0.67) existed between the degree of ownership security and farm investment per unit of land. Villamizer (1984) found that in three Brazilian states, investment per hectare is substantially greater on titled land than on undocumented or encroached land. Survey results from Jamaica indicate that the incidence of permanent and semi-permanent crops was substantially higher among titled farmers than among untitled farmers- almost twice as high. Indeed, a third of the recipients of titles under a government program reported that following the change in their status they planted more permanent and semi-permanent crops than they did before the initiation of the project (IDB, 1986).

Some studies have discussed the relationship between land registration and output or income. Mosher (1966) asserted that tenure insecurity is an important source of low productivity in agriculture. Sales et al (1970) estimated a positive correlation of 0.53 between income per unit of land and security of ownership, in one province in Costa Rica. A study conducted by IDB (IDB, 1986) concluded that granting full legal ownership to squatters and undocumented occupiers in the state of Maranhao in Brazil increased their income by about $200 \%$. The same study also found that income levels of titled farmers in Ecuador were twice those of untitled farmers, when the amount of land owned was held constant.

The level of econometric rigor of these earlier studies, however, was not adequate to support a firm conclusion on the magnitude of the economic impact generated by land registration systems, as the influence of other factors affecting economic performance was not fully controlled in the analyses (Feder and Nishio, 1999). The above literature was therefore followed by a series of detailed, country-specific and empirical studies which were conducted from the mid-1980s, where the economic benefits of land registration were analyzed using more rigorous quantitative methods. These are reviewed as follows: Feder et al (1988) used econometric analysis to compare the economic performance of two groups of farmers: those without legal titles who operate in forest reserve areas, and another group of farmers with legal titles operating outside the forest reserve boundaries. Study sites were selected carefully in four provinces, so that the two groups within a site operated in geographical proximity, and within a similar agro-climatic environment.

The effect of land registration on farmers' access to credit was clearly established. It was shown that when taking into account both the direct effect of land being available as collateral and the indirect effect of greater and value resulting from a title, titled farmers who provide land as collateral are offered significantly more institutional credit than untitled farmers. Farmers with legal titles had access to 52-521\% more institutional credit than those without.

Difference in economic performance between titled and untitled farmers were also clearly established. Per unit of land, titled farmers invested in land, used more inputs, and generated higher output than untitled farmers. This translated into higher revenue (agricultural and non-agricultural) by 14.5 to $20.8 \%$, and higher land price by $25.0 \%$ to132.6\%. The economic models used in Feder et al (1988) were applied to measure the effects of transferable land rights on credit, land investment and land use in rural India(Pender and Kerr, 1994).

The study surveyed the poor rice-growing villages of Aurepalle and Dokur in Andra Pradesh, sampling 165 and 126 households respectively. To assess the benefits of land transferability, comparison was made between titled (transferable) land and "assigned" land, which is land granted to the poor under the government's land distribution schemes (officially non-transferable, except to the heirs of the recipients). Econometric analysis showed that the land rights status, namely its transferability, has had little effect on investment or credit. In fact, differences between titled land and assigned land, in terms of credit use and investment, appear to be due mostly to differences in the quality of the land. On the other hand, the study found that the land rights status affects land values significantly: assigned land is worth $15 \%$ less than titled land of comparable quality, owing to lack of transferability. 
These results are thus not fully internally consistent, although the explanation offered by the paper is consistent with the conceptual model put forth in Feder et al (1988). In a nutshell, the paper submits that transferable rights have had little effect on credit and investment because formal credit is rarely available in these area(while informal credit is abundant), and consequently formal credit is largely irrelevant to marginal decisions about investment. This explanation is consistent with a specific finding in Feder et al (1988), that the impact of title was relatively unimportant in one study area where informal lending was predominant. The difference in land value suggests, however, that there is a premium for the transferability, while the investment effect may be too small to be detected by the econometric work.

3. Business Environment and Access to Credit for Business Operators in Nigeria

The Nigerian business environment offers many entrepreneurial opportunities. For this reason, several programmes and policies were put in place by both the Federal and State government to encourage entrepreneurial activities in the country. Notable among such programmes were the establishment of Industrial Development Centres across the country (1960-70), the Small Scale Industries Credit Guarantee Scheme (SSICS) 1971, specialized financial schemes through development financial institutions such as the Nigerian Industrial Development Bank (NIDB) 1964, Nigerian Bank for Commerce and Industry (NBCI) 1973, and the National Economic Recovery Fund (NERFUND) 1989. All of these institutions merged to form the Bank of Industry (BOI) in 2000. Also in 2000, Government also merged the Nigeria Agricultural Cooperative Bank (NACB), the People's Bank of Nigeria (PBN) and Family Economic Advancement Programme (FEAP) to form the Nigerian Agricultural Cooperative and Rural Development Bank Limited (NACRDB). The Bank was set up to enhance the provision of finance to the agricultural and rural sector. Government also facilitated and guaranteed external finance by the World Bank (including the SME I and SME II loan scheme) in 1989, and established the National Directorate of Employment (NDE) in 1986 (Babajide, 2011).

In 2003, the Small and Medium Enterprise Development Agency of Nigeria (SMEDAN), an umbrella agency to coordinate the development of the SME sector was established. In the same year, the National Credit Guarantee Scheme for SMEs to facilitate its access to credit without stringent collateral requirements was reorganized and the Entrepreneurship Development Programme was revived. Just like other government initiative programmes in the country, all the programmes failed to achieve expected result in the SME sector. In 1999, the banks through its representatives 'the Banker's Committee' at its 246th annual general meeting held on December 21, 1999. The banks agreed to set aside $10 \%$ of their profit before tax (PBT) annually for equity investment in small and medium scale industries. The scheme aimed, among other things, to assist the establishment of new, viable SMI projects; thereby stimulating economic growth, and development of local technology, promoting indigenous entrepreneurship and generating employment. Timing of investment exit was fixed at minimum of 3 years. The fund was called Smal land Medium Industries Equity Investment Scheme (SMIEIS) fund. The fund also failed due to slow utilization of the available fund. The thrust of controversy is in the desire of the Banks to acquire controlling shares in the funded enterprises and the entrepreneurs' resistance to submit control; also inability of the banks to adapt equity investment which is quite different from what the banks are familiar with in credit appraisal and management and lack of proper structure for effective administration of the scheme when it took off among other factors. The failure of all of these programmes put together necessitates the need for alternative financing window for SMEs in Nigeria. The Microfinance Policy Regulatory and Supervisory Framework (MPRSF) was launched in 2005(Babajide, 2011). The policy among other things, addresses the problem of lack of access to credit by small business operators who do not have access to regular bank credits. It is also meant to strengthen the weak capacity of such entrepreneurs, and raise the capital base of microfinance institutions. The objective of the microfinance policy is to make financial services accessible to a large segment of the potentially productive Nigerian population, which have had little or no access to financial services and empower them to contribute to rural transformation.

3.1. Land Ownership in Nigeria

Land ownership in Nigeria is regulated by the Lands Use Act Cap 202 Volume 11 Laws of the Federation, 1990 (Olofinji, 2015). The law vests ownership of all land within a state (except those vested in the Federal Government or its agent) in the Governor of the state who holds land in trust for the people and allocate same as far as the urban area is concerned, to individuals and corporate entities for residential, commercial, agricultural and other purposes allowed by law. Land located in rural areas is under the control of local government authorities.

Documentary evidence of ownership is called title deeds or title documents. Ownership of land before the Land Use Act was either by settlement, conquest, sale, gift or larches and acquiescence. With the promulgation of the Land Use Act, ownership acquired by the above methods became extinguished and became vested in the Governor of the state. Freehold interest acquired prior to the Act became convened to leasehold, the Governor becoming the lessor. 
A lease granted by the Governor is usually for 99 years, subject to review upon expiration. The terms of the lease are, under the Land Use Act, contained in a Certificate of Occupancy ( $\mathrm{C}$ of $\mathrm{O}$ ) granted by the Governor. The $\mathrm{C}$ of 0 , which is the document of title provided for under the Act, grants a right of occupancy for the leasehold term stipulated therein (Olofinji, 2015).

Documents of title obtained and registered at the lands registry prior to the advent of the $\mathrm{C}$ of $\mathrm{O}$ do not by that fact lose their validity. They remain valid subject to the general condition that freehold interests purportedly conveyed in them have now been convened to leasehold held at the governor's mercy. Holders of such title documents, usually called a Deed of Conveyance, Deed of Gift etc., are deemed by law to have a statutory right of occupancy over the land.

Even where title to land, prior to the operation of the Land Use Act, is not evidenced by a registered document, or held under customary law, the holders of such title are also deemed to have a statutory right of occupancy. Such title-holders are however at liberty (and advisable) to apply to the Governor for a $\mathrm{C}$ of $\mathrm{O}$ as written / registered evidence of their title to the same.

The Land Use Act does not abolish any prior interest in, or the right of the holder of a title to, land to freely transfer or deal with the same. The only condition imposed on such right is that it is exercisable subject to the consent of the Governor, in line with his ownership thereof. Therefore, in order to validate a transfer of title, the transferor by law (but usually the transferee in practice) must apply for the Governor's consent to the Deed of Assignment duly executed by the parties. This is followed by stamping at the Stamp Duties office and registration at the Lands Registry (Olofinji, 2015).

After endorsement of the Governor's consent, stamp duty is paid on the document and the same registered at the lands registry. It is worthy of note that the requirements differ from state to state and are subject to review from time to time.

\section{Research Methodology}

The multiple-method strategy was adopted for this study. The study was designed to combine primary survey based data with secondary information extracted from journals, newspapers, websites, blogs, etc. The purpose of extracting information from such sources is to obtain some independent confirmation of information and data, as well as a range of opinions. The theoretical population of the study consists of the entire business operators in the country. However, the study was restricted to north-central geopolitical zone, Nasaraw state to be specific. The choice of Nasarawa state was due to the many solid mineral resources endowment and business operatives (small and medium scale enterprises) such as mining, trading, agriculture, services, manufacturing, etc.

\subsection{Area of Study: Nasarawa State, Nigeria}

Located in the continent of Africa, Nigeria covers 910,768 square kilometers of land and 13,000 square kilometers of water, making it the 32nd largest nation in the world with a total area of 923,768 square kilometers (World Atlas, 2016). Nigeria shares its international boundaries with the Republic of Benin to the west, Cameroon and Chad to the east, and Niger to the north. Towards the south, Nigeria is bordered by the Gulf of Guinea on the Atlantic Ocean. Nigeria is home to an overall population of 170,123,740 (2012 estimate) (Map of World, 2017). It is the most populous country on the African continent and the seventh most populous country in the world. Coal, tin, and crude oil are some of the important industrial products and palm oil, rubber, rice, cocoa, millets, and peanuts are the key agricultural products of Nigeria. The economy of Nigeria is one of the fastest growing economies in the world. As of 2015 , Nigeria was the world's 20th largest economy, worth more than $\$ 500$ billion and $\$ 1$ trillion in terms of nominal GDP and purchasing power parity respectively (Wikipedia, 2017). Nigeria is divided into 36 states and one federal capital territory.

Nasawara state is one of the states in Nigeria and it is the focus of the study. Created on October 1, 1996, Nasawara state covers a total area of $27,117 \mathrm{~km}^{2}(10,470 \mathrm{sq} \mathrm{mi})$ and has a total population of 1,863,275 (Wikipedia, 2015) as at the 2006 census with an average population density of $75 / \mathrm{km}^{2}(190 / \mathrm{sq} \mathrm{mi})$ and a total GDP (2010) of $\$ 3,022$ Million, at \$1,588 Per Capita (Services.gov.ng, 2016). It is, however, estimated that the population of the state has since geometrically increased to the figure of 2.6million people at present (Adogi, 2013). 


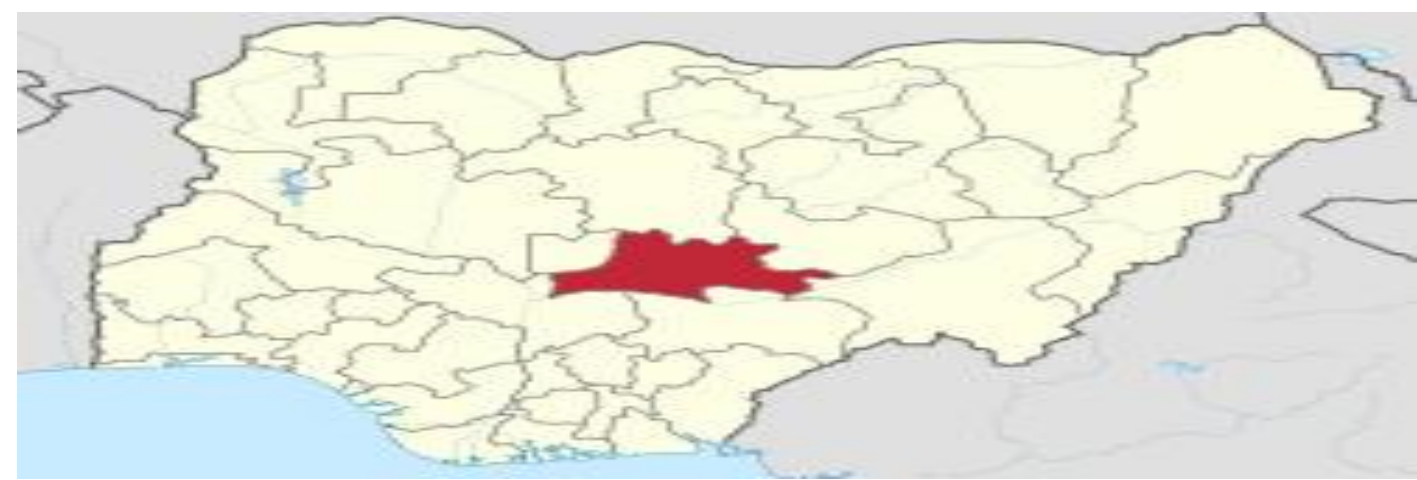

Figure 1. Location of Nasarawa state in Nigeria

Source: Wikipedia (2016)

The State has three National Senatorial Districts (South, North and West). Nasarawa State consists of thirteen (13) Local Government Areas (shown with 2006 population figure) (see table 1):

Table 1. Local Government Areas in Nasarawa State

\begin{tabular}{|c|c|c|c|c|c|}
\hline $\begin{array}{l}\text { Nasarawa } \\
\text { West } \\
\text { Senatorial } \\
\text { District }\end{array}$ & $\begin{array}{l}\text { Total } \\
\mathbf{7 1 6 , 8 0 2}\end{array}$ & $\begin{array}{l}\text { Nasarawa } \\
\text { North } \\
\text { Senatorial } \\
\text { District }\end{array}$ & $\begin{array}{l}\text { Total } \\
\mathbf{3 3 5 , 4 5 3}\end{array}$ & $\begin{array}{l}\text { Nasarawa } \\
\text { South } \\
\text { Senatorial } \\
\text { District }\end{array}$ & $\begin{array}{l}\text { Total } \\
\mathbf{8 1 1 , 0 2 0}\end{array}$ \\
\hline Karu & 205,477 & Akwanga & 113,430 & Awe & 112,574 \\
\hline Keffi & 92,664 & Nasarawa Egon & 149,129 & Doma & 139,607 \\
\hline Kokona & 109,749 & Wamba & 72,894 & Keana & 79,253 \\
\hline Nasarawa & 189,835 & & & Lafia & 330,712 \\
\hline Toto & 119,077 & & & Obi & 148,874 \\
\hline
\end{tabular}

Source: Wikipedia(2015).

Nasarawa has a diverse range of ethnic groups indigenous to the state. The State is bounded in the north by Kaduna State, in the west by the Abuja Federal Capital Territory, in the south by Kogi and Benue States and in the east by Taraba and Plateau States. Nasarawa State has agriculture as the mainstay of its economy with the production of varieties of cash crops throughout the year. It has a wide range of solid minerals and a variety of crops produced within the state. At the moment, the commercial life of the state is dominated by the operations of the rural markets. Apart from Lafia and Karu, all other markets are periodic, including Keffi and Akwanga markets (Fmdqotc, 2013). Also, the abundant mineral and agricultural resources in Nasarawa State provide a good and solid base for rapid industrialization (see table 2).

Table 2. Solid Minerals in Nasarawa State

\begin{tabular}{llll}
\hline S/N & LGA / Locality & Minerals \\
\hline 1 & Akwanga & Cassiterite, Clay, Columbite, Mica, Grannite, Limenite \\
\hline 2 & Awe (Azara, Wuse, Aloshi) & Baryte, Clay, Galena, Salt, Limestone & \\
\hline 3 & Doma & Clay, Silica sand & \\
\hline 4 & Keana & Baryte, Galena, Salt, Zinc, Lead, Limestone & \\
\hline 5 & Karu(Panda) & Clay, Glass sand, Granite, Tantalite, Mica & \\
\hline 6 & Keffi(Ungwar Doka, Tudun Jenjela) & $\begin{array}{l}\text { Clay, Tale, Gemstone(Tourmaline, Aquamarine, } \\
\text { Sapphire) }\end{array}$ \\
\hline 7 & Kokona(Bakin-Aini, Rafin Gabas) & $\begin{array}{l}\text { Mica, Chalcopyrite, Gemstone (Tourmaline and } \\
\text { Aquamarine) }\end{array}$ \\
\hline 8 & Lafia (Shabu) & Clay, Silica sand, Gemstone (Topaz) \\
\hline 9 & $\begin{array}{l}\text { Nassarwa Eggon (Wana, Alogani, Mada } \\
\text { station, Ungwar Gyawa) }\end{array}$ & $\begin{array}{l}\text { Quartz, Mica, Granite, Gemstone (Emerald, Aquamarine, } \\
\text { Heliodor, Topaz, Amethyst) }\end{array}$ \\
\hline
\end{tabular}




\begin{tabular}{llll}
\hline 10 & Obi & Baryte, Clay Coal & \\
\hline 11 & Nassarawa(Udege-mbeki) & Cassiterite, Clay, Columbite, Tantalite & \\
\hline 12 & Toto (Ugya) & Marble, Iron ore, Mica & \\
\hline 13 & Wamba( Randa, Gongon) & $\begin{array}{l}\text { Cassiterite, Tantalite, Granite, Columbite, limonite, } \\
\text { Aquamarine }\end{array}$ & \\
\hline
\end{tabular}

Source: NSN (2015)

\subsubsection{Registering Property in Nasarawa State}

Here is a detailed summary of the steps involved in registering property in Nasafawa state. It assumes a standardized case of an entrepreneur who wants to purchase land and a building that is already registered and free of title dispute (World Bank, 2016).

a) Pay search fee at designated bank

The fee is now paid at the bank. Once approval is granted, the property files are released to the applicant to conduct the search.

b) Conduct search of property title at NAGIS (Nasawara Geographic Information System)

The applicant writes an application letter addressed to the Commissioner for Lands requesting permission to conduct a search, and submits the letter with proof of payment of the NGN 5,000 search fee.

c) Execute deed of assignment at lawyer's office

The seller and buyer sign the deed of assignment prepared by a lawyer. Legal fees are charged based on the Scale of Fees for Conveyancing Matters [Legal Practitioners (Remuneration for Legal Documentation and other Land Matters) Order 1991]. In Nasarawa state, legal fees for registering property average 7\% of the value of the property. The fees include all the steps required until the new title is registered under the buyer's name.

d) Submit application for Governor's consent to the assignment at NAGIS (Nasawara Geographic Information System)

The deed is submitted to the NAGIS (Nasawara Geographic Information System) for assessment of registration and consent fees.

e) Receive inspection of property from NAGIS (Nasawara Geographic Information System)

The site is inspected by an official valuer in order to determine the value of the property based on which the fees will be calculated (assessment of the fiscal value).

f) Pay fees at designated bank

Consent, site inspection and registration fees are paid at a designated bank.

g) Obtain Certified True Copy (CTC) of title document at NAGIS (Nasawara Geographic Information System)

The applicant is required to make a written application to the NAGIS, attach the deed, and make payment in cash.

h) Obtain Governor's consent to the assignment at Ministry of Lands, Survey, and Town Planning

By virtue of the Lands Use Act, promulgated in 1978, all land in each state in the Federation became vested in the Governor of that state, whose prior consent is mandatory for the legal validity of any transfers or alienation of interest in landed property. The application for consent should be accompanied by the following documents:

a. Proof of payment of the required fees;

b. Three year tax clearance for the seller and buyer's companies;

c. Four bound copies of the executed deed of assignment.

It takes 1 day to submit the documentation and 90 days to obtain consent.

i) Assess deed of assignment at Stamp Duty Office

The applicant takes the deed to the Stamp duty Office/Federal Inland Revenue Service (FIRS) to have it assessed.

j) Pay stamp duty at designated bank

The applicant pays the assessed stamp duty at one of the designated banks.

k) Stamp deed of assignment at Stamp Duty Office

Once the required duties have been paid, the applicant goes to the FIRS with receipt of payment for the deed to be stamped.

l) Register deed of assignment at NAGIS (Nasawara Geographic Information System)

After the deed has been stamped, it is registered.

4.2. Data Source and Technique of Estimate

As earlier mentioned, the study adopted a survey method. The participants for the study were drawn from a population of business operators in four selected towns from four selected local government areas in Nasarawa state. However, 420 respondents fully participated in the study. Structured questionnaire was the main instrument of data 
collection. The decision to structure the questionnaire is predicated on the need to reduce variability in the meaning possessed by the questions as a way of ensuring comparability of responses. The questionnaire was designed to seek information on socio-demographic variables as well as the respondent's perception on the issue of stunt business growth due to difficulty in obtaining Land Title Documents. The questions in the questionnaires were closed ended questions.

In all, a total of 420 copies of the questionnaire were returned out of 450 copies administered. This represents a total response rate of $93.3 \%$. The high return rate achieved from the field survey can be attributed to the support received from the business operators visited. Precisely, 120 questionnaires were retrieved from Lafia, 82 questionnaires from Keffi, 102 questionnaires from Maraba/Masaka and 116 questionnaires from Eggon/Akwanga. The results of the study were analyzed using cross-tables, simple percentage counts, mean value and chi-square test.

5. Findings and Discussions

A) Socio-demographic Information/Data of Respondents

The bar chart below depicts the distribution of respondents based on gender (Figure 2). It shows that out of the 420 sampled respondents, 265 were male and 155 were female. A further break down of gender is shown in Table 3. It shows that in Lafia, male respondents were 70 while female respondents were 50.

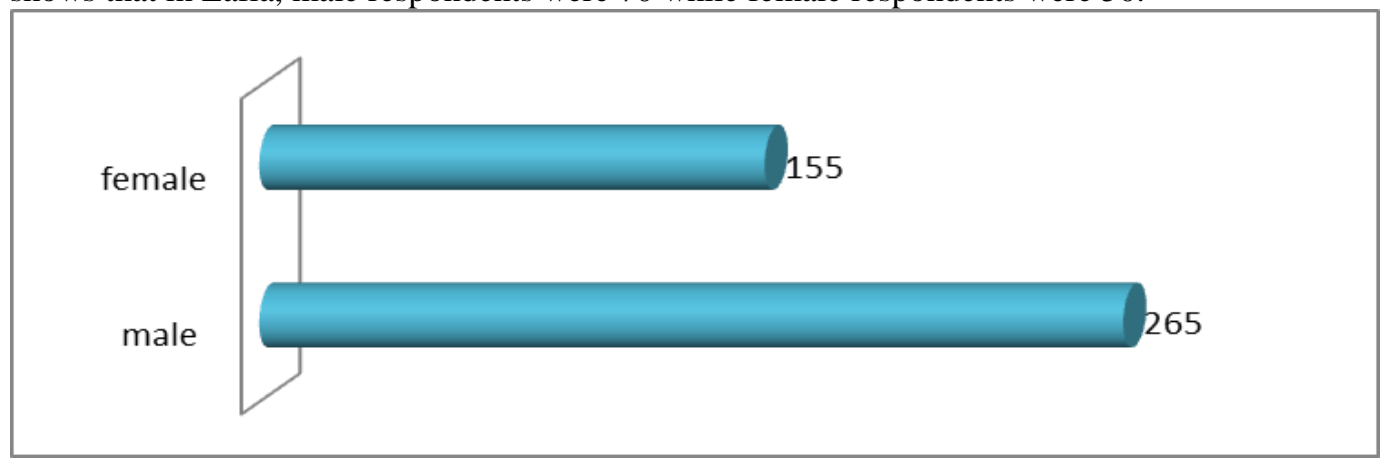

Figure 2.Distribution of respondents based on gender

Source: Field Survey.

A total of 82 respondents were obtained in Keffi; 50 were male and 32 female. The table also revealed that in Maraba/Masaka, female respondents were 21 in number while the male respondents were overwhelming by a total number of 81. In Eggon/Akwanga, 64 respondents were male while 52 were female.

Table 3. Distribution of respondents by Sex

\begin{tabular}{|c|c|c|c|c|c|c|}
\hline \multirow[t]{2}{*}{ Sex } & \multicolumn{4}{|c|}{ Frequency } & \multirow{2}{*}{ Total } & \multirow{2}{*}{$\begin{array}{l}\text { As \% of Total } \\
(\mathrm{N}=420)\end{array}$} \\
\hline & Lafia & Keffi & Maraba/Masaka & Eggon/Akwanga & & \\
\hline Male & 70 & 50 & 81 & 64 & 265 & 63.10 \\
\hline Female & 50 & 32 & 21 & 52 & 155 & 36.90 \\
\hline Total & 120 & 82 & 102 & 116 & 420 & 100 \\
\hline
\end{tabular}

Source: Field Survey.

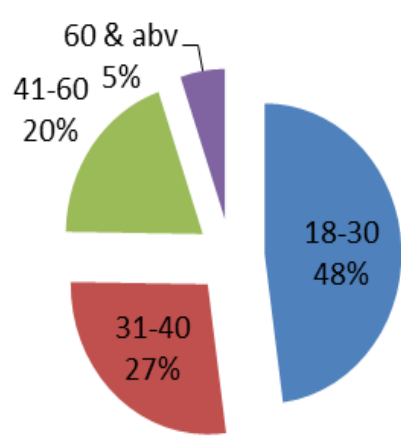

Figure 3. Percentage distribution of respondents by age 
The pie chart above reveals that $48 \%$ (201 respondents) of the respondents fall between 18 - 30 years. The respondents within the age range of 31-40 years make up 27\% (115 respondents) of the total respondents. $20 \%$ ( 82 respondents) of the respondents were under 41-60 years. 5\% (22 respondents) of respondent were above 60years.

Table 4. Distribution of respondents by age

\begin{tabular}{|c|c|c|c|c|c|c|c|c|c|}
\hline \multirow[t]{2}{*}{ Age } & \multicolumn{4}{|c|}{ Frequency } & \multirow[t]{2}{*}{ Total } & \multicolumn{4}{|c|}{ Group Data (Arithmetic Mean) } \\
\hline & Lafia & Keffi & Maraba/Masaka & Eggon/Akwanga & & Age & $\begin{array}{l}\text { Frequeny } \\
\text { (F) }\end{array}$ & $\begin{array}{l}\text { Mid } \\
\text { Point } \\
(\mathrm{X})\end{array}$ & FX \\
\hline $\begin{array}{l}18- \\
30 y r s\end{array}$ & 82 & 29 & 34 & 56 & 201 & $\begin{array}{l}18- \\
30 y r s\end{array}$ & 201 & 24 & 4,824 \\
\hline $\begin{array}{l}31- \\
40 y r s\end{array}$ & 23 & 21 & 42 & 29 & 115 & $\begin{array}{l}31- \\
40 y r s\end{array}$ & 115 & 35.5 & $4,059.5$ \\
\hline $\begin{array}{l}41- \\
60 y r s\end{array}$ & 15 & 21 & 26 & 20 & 82 & $\begin{array}{l}41- \\
60 y r s\end{array}$ & 82 & 50.5 & 4,141 \\
\hline $\begin{array}{l}\text { Above } \\
60 \mathrm{yrs}\end{array}$ & 0 & 11 & 0 & 11 & 22 & $\begin{array}{l}61- \\
100 \\
\text { yrs }\end{array}$ & 22 & 80.5 & 1,771 \\
\hline Total & 120 & 82 & 102 & 116 & 420 & & 420 & & $14,795.5$ \\
\hline
\end{tabular}

Source: Field Survey.

Arithmetic mean: $=14,795.5 / 420=35.2$

Table 4 above reveals that respondents whose ages fall between 18 - 30 years were $82,29,34$ and 56 in number from Lafia, Keffi, Maraba/Masaka and Eggon/Akwanga respectively. 31-40yrs age bracket had 23 respondents from Lafia, 21 respondents from Keffi, 42 respondents from Maraba/Masaka and 29 respondents from Eggon/Akwanga. Those under 41-60 years totaled 15 from Lafia, 21 from Keffi, 26 from Maraba/Masaka and 20 from Eggon/Akwanga. According to Table 4, there was no respondent above 60 years from Lafia and Maraba/Masaka. Nonetheless, Keffi and Eggon/Akwanga each had 11 respondents well above 60 years. Given the different age brackets of the 420 respondents, the arithmetic mean age is 35.2 years.

Table 5. Distribution of respondents by marital status

\begin{tabular}{|c|c|c|c|c|c|c|}
\hline \multirow{2}{*}{$\begin{array}{l}\text { Marital } \\
\text { Status } \\
\end{array}$} & \multicolumn{4}{|c|}{ Frequency } & \multirow[t]{2}{*}{ Total } & \multirow{2}{*}{$\begin{array}{l}\text { As } \% \text { of } \\
\text { Total } \\
(\mathrm{N}=\mathbf{4 2 0})\end{array}$} \\
\hline & Lafia & Keffi & Maraba/Masaka & Eggon/Akwanga & & \\
\hline Single & 67 & 44 & 50 & 43 & 204 & 48.57 \\
\hline Married & 40 & 38 & 52 & 63 & 193 & 45.95 \\
\hline Divorced & 13 & 0 & 0 & 10 & 23 & 5.48 \\
\hline Total & 120 & 82 & 102 & 116 & 420 & 100 \\
\hline
\end{tabular}

Source: Field Survey.

According to Table 5, out of 120 respondents in Lafia, 67 were single, 40 were married and 13 were divorced. In $\mathrm{K}$ effi, no respondent was divorced, however, 44 were single while 38 were married. The number of respondents married in Maraba/Masaka were 52 while 50 were single. It appeared that no respondent was divorced in Maraba/Masaka. A closer look at Table 5 shows that 10 respondents were divorced, 43 were single and 63 were married out of a total of 116 respondents.

Table 6. Distribution of respondents by qualification

\begin{tabular}{|c|c|c|c|c|c|c|}
\hline \multirow{2}{*}{$\begin{array}{l}\text { Type of } \\
\text { Qualification }\end{array}$} & \multicolumn{4}{|c|}{ Frequency } & \multirow[t]{2}{*}{ Total } & \multirow{2}{*}{$\begin{array}{l}\text { As \% of } \\
\text { Total } \\
(\mathrm{N}=420)\end{array}$} \\
\hline & Lafia & Keffi & Maraba/Masaka & Eggon/Akwanga & & \\
\hline Primary/College & 22 & 22 & 34 & 19 & 97 & 23.10 \\
\hline ND/NCE & 67 & 34 & 40 & 53 & 194 & 46.19 \\
\hline B.Sc/HND & 31 & 15 & 17 & 25 & 88 & 20.95 \\
\hline Masters/Above & 0 & 11 & 11 & 19 & 41 & 9.76 \\
\hline
\end{tabular}


www.cribfb.com/journal/ijmri International Journal of Marketing Research Innovation Vol. 2, No. 1; 2018

\begin{tabular}{lllllll}
\hline $\begin{array}{l}\text { No formal } \\
\text { education }\end{array}$ & 0 & 0 & 0 & 0 & 0 & 0 \\
\hline Total & 120 & 82 & 102 & 116 & 420 & 100 \\
\hline
\end{tabular}

Source: Field Survey.

From Table 6, qualification of respondents from Lafia showed that 22 respondents possessed Primary/College certificates, 67 had ND/NCE, 31 B.Sc/HND, none had Masters degree and above. Also, there was no respondent who had no formal education. The table revealed clearly that respondents with Primary/College certificates were 22, ND/NCE were 34, B.Sc/HND were 15, Masters/Above 11, and no respondent without formal education. Primary/College respondents for Maraba/Masaka and Eggon/Akwanga were 34 and 19 respectively. ND/NCE holders among the respondents in Maraba/Masaka were 40 while that of Eggon/Akwanga were 53. According to the table, B.Sc/HND respondents were 25 from Eggon/Akwanga and 17 from Maraba/Masaka. Those respondents having Master degree and above in Maraba/Masaka and Eggon/Akwanga were 11 and 19 respectively. The qualification having the highest number of respondents is ND/NCE (67) and it was experienced in Lafia.

Table 7. Distribution of respondents by nature of business

\begin{tabular}{|c|c|c|c|c|c|c|}
\hline \multirow{2}{*}{$\begin{array}{l}\text { Nature of } \\
\text { Business }\end{array}$} & \multicolumn{4}{|c|}{ Frequency } & \multirow[t]{2}{*}{ Total } & \multirow{2}{*}{$\begin{array}{l}\text { As \% of } \\
\text { Total } \\
(\mathrm{N}=420)\end{array}$} \\
\hline & Lafia & Keffi & Maraba/Masaka & Eggon/Akwanga & & \\
\hline Trading & 54 & 38 & 35 & 47 & 174 & 41.43 \\
\hline Manufacturing & 17 & 20 & 12 & 15 & 64 & 15.23 \\
\hline Services & 24 & 24 & 30 & 17 & 95 & 22.62 \\
\hline Agriculture & 6 & 0 & 8 & 9 & 23 & 5.48 \\
\hline Mining & 6 & 0 & 5 & 12 & 23 & 5.48 \\
\hline Others & 13 & 0 & 12 & 16 & 41 & 9.76 \\
\hline Total & 120 & 82 & 102 & 116 & 420 & 100 \\
\hline
\end{tabular}

Source: Field Survey.

Table 7 attempts to describe or show the nature of business or commerce which the respondents were into. In Lafia, a huge number (54) of the respondents were into trading. This is followed by services (24) and manufacturing (17). Similar, trend of business activities are exhibited in Keffi, Maraba/Masaka, and Eggon/Akwanga.

Table 8. Distribution of respondents by type of business

\begin{tabular}{|c|c|c|c|c|c|c|}
\hline \multirow[t]{2}{*}{ Types of Business } & \multicolumn{4}{|c|}{ Frequency } & \multirow[t]{2}{*}{ Total } & \multirow{2}{*}{$\begin{array}{l}\text { As \% of } \\
\text { Total } \\
(\mathrm{N}=420)\end{array}$} \\
\hline & Lafia & Keffi & Maraba/Masaka & Eggon/Akwanga & & \\
\hline Sole Proprietorship & 79 & 56 & 72 & 51 & 258 & 61.43 \\
\hline Partnership & 21 & 26 & 16 & 24 & 87 & 20.71 \\
\hline $\begin{array}{l}\text { Limited Liability } \\
\text { Company }\end{array}$ & 11 & 0 & 14 & 18 & 43 & 10.24 \\
\hline $\begin{array}{l}\text { Cooperative } \\
\text { Society }\end{array}$ & 9 & 0 & 0 & 23 & 32 & 7.62 \\
\hline Total & 120 & 82 & 102 & 116 & 420 & 100 \\
\hline
\end{tabular}

Source: Field Survey.

Table 8 attempts to categorize the business entities operated by the respondents. Clearly, sole proprietorship is the leading form of business operated by the respondents in Lafia (79 respondents), Keffi (56 respondents), Maraba/Masaka (72 respondents), and Eggon/Akwanga (51 respondents). The table reveals also that partnership form of business thrives in these areas.

B) Stunted Business Growth due to Lack of Land Title Documents (Certificate of Occupancy)

Table 9. Do you have land title document (Certificate of Occupancy) to your business premises?

\begin{tabular}{cccccc}
\hline & Responses & Frequency & Percent & Valid Percent & Cumulative Percent \\
\hline Valid & Yes & 148 & 35.24 & 35.24 & 35.24 \\
\hline
\end{tabular}


www.cribfb.com/journal/ijmri International Journal of Marketing Research Innovation Vol. 2, No. 1; 2018

\begin{tabular}{lllll}
\hline No & 272 & 64.76 & 64.76 & 100 \\
\hline Total & 420 & 100 & 100 & \\
\hline
\end{tabular}

Source: Field Survey.

When respondents were asked if they have Land Title Documents or Certificate of Occupancy to their business premises, a small proportion responded yes (35.24\%). However, a large proportion responded no (64.76\%) as depicted in Table 9. A Certificate of Occupancy ( $\mathrm{C}$ of $\mathrm{O}$ ) is a document issued by Authorities to a land owner as evidence of ownership of land. It contains the terms and conditions for the grant of the land. A C of $\mathrm{O}$ is issued by the Governor of a state or the President in the case of Federal Capital Territory (FCT) which power he exercises through the Minister of FCT. It is issued after a person has applied for a grant of right of occupancy and is so granted the right. After the requirements are met, the Certificate is issued as Evidence of Title (Fola, 2013).

Table 10. Have you ever made a request for ' $\mathrm{C}$ of O' from the government agency before?

\begin{tabular}{llllll}
\hline & Responses & Frequency & Percent & Valid Percent & Cumulative Percent \\
\hline Valid & Yes & 160 & 38.10 & 38.10 & 38.10 \\
\hline No & 260 & 61.90 & 61.90 & 100 \\
\hline Total & 420 & 100 & 100 & \\
\hline
\end{tabular}

Source: Field Survey.

In Table 10, when respondents were asked if they have ever made a request for Land Title Documents to their business premises ( or ' $\mathrm{C}$ of O') from the government agency before, $38.10 \%$ indicated yes while majority of respondents (61.90\%) specified no. Although land is an advantageous form of collateral due to the fact that it cannot be removed and does not easily devalue, it is widely believed that many borrowers face barriers securing transactions with land simply because ownership rights are not formally documented (Field and Torero, 2004).

Table 11. Have you been granted the title document and how long is the processing?

\begin{tabular}{lllll}
\hline Responses & Frequency & Percent & Valid Percent & Cumulative Percent \\
\hline Yes, months/years & 168 & 40.00 & 40.00 & 40.00 \\
\hline No, months/years & 252 & 60.00 & 60.00 & 100 \\
\hline Total & 420 & 100 & 100 & \\
\hline
\end{tabular}

Source: Field Survey.

In an attempt to investigate if respondents have been granted title documents and the duration of the processing, Table 11 reveals that $60.00 \%$ of respondents responses were No and that it takes months/years. On the hand, $40.00 \%$ of respondents reported yes and that the processing takes months/years. According to Delta State Governor, Dr Ifeanyi Okowa, the process of obtaining Certificate of Occupancy C-of-O) in Delta State( as well as Nasarawa state or any other states in Nigeria) has over the years become very long, arduous, unwieldy, and opaque, often resulting in unofficial payments far in excess of the approved amount (Omon-Julius, 2016).

Table 12. Does your bank request for ' $\mathrm{C}$ of O' before granting loan facilities?

\begin{tabular}{lll}
\hline Responses & Frequency & Percentage \\
\hline Yes often & 127 & 30.24 \\
\hline Yes sometimes & 106 & 25.24 \\
\hline Never & 187 & 44.52 \\
\hline Total & 420 & 100 \\
\hline
\end{tabular}

Source: Field Survey.

According to Henssen (1990), the supply of credit, especially from institutional or formal resources (e.g. Banks), depends usually on the borrower's ability to provide documented evidence of ownership of land. When the issue of banks requesting for ' $\mathrm{C}$ of $\mathrm{O}$ ' before granting loan facilities was raised, $44.52 \%$ of respondents reported that never have banks made such request. One plausible reason for that is the fact that in much of the developing world (including Nigeria), a large percentage of both rural and urban property are untitled (Holden, 1997). 25.24\% of respondents report that 'yes, sometimes' banks demand for ' $\mathrm{C}$ of C' before loan facilities are provided while $30.24 \%$ of respondents' indicated 'yes, often' (see Table 12). This result is not surprising, it affirms McKechnie (2005) 
position that in an individual-lending scheme, collateral is usually required to reduce the bank's default risk. If the borrower does not have collateral, a bank will use moveable capital or a guarantor to secure its investment.

Table 13. Does the possession of ' $\mathrm{C}$ of O' document enhances your capital based and business expansion?

\begin{tabular}{lllll}
\hline Responses & Frequency & Relative Frequency & Percentage & Pie Section \\
\hline Significantly & 74 & 0.18 & 17.62 & $74 / 420 \times 360=63.4^{\circ}$ \\
\hline Moderately & 86 & 0.20 & 20.48 & $86 / 420 \times 360=73.7^{\circ}$ \\
\hline Not sure & 90 & 0.21 & 21.43 & $90 / 420 \times 360=77.2^{\circ}$ \\
\hline No & 170 & 0.41 & 40.47 & $170 / 420 \times 360=145.7^{\circ}$ \\
\hline Total & 420 & 1.00 & 100 & $360^{\circ}$ \\
\hline Sour
\end{tabular}

Source: Field Survey.

Economic analysis has long recognized the importance of secure property rights for growth (Deininger, 2003). From the responses in Table 13, 40.47\% of respondents are of the view that possession of ' $\mathrm{C}$ of $\mathrm{O}$ ' document does not enhance their capital based and business expansion. $21.43 \%$ of respondents were not sure while $20.48 \%$ think that the possession of $\mathrm{C}$ of $\mathrm{O}^{\prime}$ document does moderately enhance their capital based and business expansion. $17.62 \%$ of respondents were of the opinion that possession of the document does significantly enhance their capital and as well as business expansion.

However, a Chi-Square test was conducted to show the statistical significance of these responses at 5\% level (see Table 14). Since the computed value of chi-square $\left(\chi^{2}=25.51\right)$ exceeded the critical value $(7.815)$ given the degree of freedom (3), we rejected the null hypothesis and concluded that the possession of ' $\mathrm{C}$ of $\mathrm{O}$ ' document does enhance capital based and business expansion?

Table 14. Contingency Table for Chi Square $\left(\chi^{2}\right)$

\begin{tabular}{llllll}
\hline Responses & $\begin{array}{l}\text { Observes } \\
\text { Freq. }\end{array}$ & $\begin{array}{l}\text { Expected } \\
\text { Freq. }\end{array}$ & $\begin{array}{l}\text { Residue }= \\
(\text { Obs } \\
\text { Exp })\end{array}$ & $-\begin{array}{l}(\text { Obs- } \\
\text { Exp)2 }\end{array}$ & Components $=($ Obs-Exp $) 2 /$ Exp \\
\hline Significantly & 74 & 105 & -31 & -961 & -9.15 \\
\hline Moderately & 86 & 105 & -19 & -361 & -3.43 \\
\hline Not sure & 90 & 105 & -15 & -225 & -2.14 \\
\hline No & 170 & 105 & 65 & 4225 & 40.23 \\
\hline Total & 420 & & & 25.51 & \\
\hline
\end{tabular}

Note: Degrees of freedom equals the number of categories of response minus 1(n-1, i.e., 3);Chi-square statistic: 25.51; critical value:7.815; alpha level is $0.05(5 \%)$.

Table 15. State (if any) problems encountered in processing for your land title document?

\begin{tabular}{l}
\hline Response \\
\hline Delay \\
\hline Source: Field Survey.
\end{tabular}

Many business operators are finding it hard perfecting their land title document while some are not making any effort to obtain the document. When asked about the problems encountered in processing for land title document, the responses of the respondents suggest that delay is a major problem in the processing. Among the reasons cited for the delays are problems with documentation and legal issues (see Table 15).

Table 16. What are your views on the cost of obtaining ' $\mathrm{C}$ of $\mathrm{C}$ ' and the procedures of same in the State?

\begin{tabular}{lllll}
\hline Responses & Frequency & Relative Frequency & Percentage & Pie Section \\
\hline Very high and cumbersome & 116 & 0.28 & 27.62 & $116 / 420 \times 360=99.4^{\circ}$ \\
\hline High and difficult & 132 & 0.31 & 31.43 & $132 / 420 \times 360=113.1^{\circ}$ \\
\hline Fair but difficult & 101 & 0.24 & 24.05 & $101 / 420 \times 360=86.6^{\circ}$ \\
\hline Moderate and simple & 71 & 0.17 & 16.90 & $71 / 420 \times 360=60.9$ \\
\hline Total & 420 & 1.00 & 100 & 360 \\
\hline
\end{tabular}

Source: Field Survey. 
In a response to a follow up question depicted in Table 16, 31.43\% of respondents were of the view that the cost of obtaining ' $\mathrm{C}$ of $\mathrm{C}$ ' is high and difficult and the procedures are the same in the State. $27.62 \%$ of respondents reported very high and cumbersome, $24.05 \%$ viewed fair but difficult while $16.90 \%$ opined moderate and simple. According to Delta State Governor, Dr Ifeanyi Okowa, "One of the biggest disincentives to investors anywhere in the world is the high cost and delays associated with acquiring the legal titles to landed property in Delta State( as well as Nasarawa state or any other states in Nigeria) (Omon-Julius, 2016).

6. Summary, Conclusion and Recommendation

Demographically, the distribution of respondents based on gender shows that 265 respondents were male and 155 were female. Majority of the respondents (48\%) fell between $18-30$ years. The respondents within the age range of 31-40 years make up 27\%. $20 \%$ of the respondents were under $41-60$ years while $5 \%$ of respondent were above 60 years. Marital status of respondents shows that $48.57 \%$ were single, $45.95 \%$ married and $5.48 \%$ divorced. The data gathered reveals that $23.10 \%$ of the business owners sampled had primary/college qualification, $46.19 \%$ possessed ND/NCE, 20.95\% were B.Sc/HND holders, 9.76\% had Masters degree and above. There was no respondent with no formal education. This development shows the literacy level of the respondents and their ability to respondent to issues raised in the questionnaire. Distribution of respondents by nature of business shows that a large percentage $(41.43 \%)$ were into trading, followed by service $(22.62 \%)$ and manufacturing $(15.23 \%)$. A few were into agriculture (5.485) and mining (5.48\%). 9.76\% were into one form of business or the other. The data gathered were also analyzed to show the type of business structures these respondents undertook. This is because business structures have legal and tax implications. The result shows that the most common forms of businesses were sole proprietorship (61.43\%) and partnership (20.71\%).

On the subject "Stunted Business Growth due to Lack of Land Title Documents (Certificate of Occupancy)", investigation reveals that a large proportion responded "no" $(64.76 \%)$ that they do not have Land Title Document to their business premises. Majority of respondents (61.90\%) specified no that they have never made a request for Land Title Documents to their business premises from the government agency before. In an attempt to investigate if respondents have been granted title documents and the duration of the processing, data revealed that $60.00 \%$ of respondents' responses were no and that it takes months/years. $44.52 \%$ of respondents reported that never have banks made request for ' $\mathrm{C}$ of $\mathrm{O}$ ' before granting loan facilities while $30.24 \%$ of respondents' indicated 'yes, often'. From the responses, $40.47 \%$ of respondents were of the view that possession of ' $\mathrm{C}$ of $\mathrm{O}$ ' document will not enhance their capital based and business expansion. Concerning problems encountered in processing for land title document, the responses of the respondents suggest that delay is a major problem in the processing. Among the reasons cited for the delays are problems with documentation and legal issues. A reasonable percentage of respondents (31.43\%) were of the view that the cost of obtaining ' $\mathrm{C}$ of $\mathrm{C}$ ' is high and difficult in the State.

Conclusively, land title documents serve as evidence of ownership of a piece of property. Registration of land property affords property owners some protection against squatters and makes the transferring or mortgaging of land easier for the persons involved. It also gives authenticity and legitimacy of business carried on any piece of property. Based on the findings, this study recommends that:

The remedy to Stunting of Business Growth is to ensure that Land Title Documents are processed on time, and as promised. It is necessary that the government agency or department handling this document should be reorganize and the necessary units created to facilitate processing. The steps required to obtain this document should be reduced in order to avoid so much back and forth movement between multiple government agencies or department. This steps should be made uniform within Nasarawa state and the whole procedure should not take several months to complete. On the part of business operators, they should ensure to consult with the appropriate authority regarding the acquisition of land from any individual or organization to avoid swindling and delay in providing title document. The state government should intesify effort at reorientating and educating the indigenes and non-indigenes doing business in the State on Land policy. Especially, individual responsibility, right of ownership, how to register therein little and the benefit of Land title registration.

7. Limitations of the Study

It is important to note that the reliability of the instrument used in this study was not verifiable. The study is based on perceptions and perceptions are subject to change from individual to individual and time to time. However, the results form a basis for further research on a wider scale.

References

Aaker, D.A., and McLoughlin, D.(2010). " Strategic Market Management: An Introduction and Overview". Strategic Market Management: Global Perspectives. Chichester, West Sussex: John Wiley \& Sons. p. 3. ISBN 978-0-470-68975-2. 
Adogi, M. (2013). Fulani-farmers Conflicts in Nasarawa State: The Ecology, Population and Politics. Abuja: Murry Greens consult.http://dailypost.ng/2013/02/09/murtala-adogi-mohammed-the-fulanifarmers-conflicts-in-nasarawa-state-the-ecology-population-and-politics/

Akrani, G. (2011). What is Busines? Meaning Definition, Features of Business. http://kalyancity.blogspot.com.ng/2011/03/what-is-business-meaning-definitions.html

Aku, P.S. (1986). Lending to Farmers through the Commercial Banks in a Developing Country: The Nigerian Experience. Agricultural Systems, 22(1), 23-32.

Ahiuma-Young, V. (2016). Poverty: 112m Nigerians Live Below Poverty Line. http://www.vanguardngr.com/2016/10/poverty-112m-nigerians-live-poverty-line/

Babajide, A. (2011).Microfinance and Micro and Small Enterprises (MSES) Survival in Nigeria -A Survival Analysis Approach. Global Journal of Management And Bussiness Research, 11(11), 79-87.

Berger, A.N., and Udell, G.F. (1990). Collateral, Loan Quality and Bank Risk. Journal of Monetary Economics $1(25), 21-42$.

Besley, T. (1995). Property Rights and Investment Incentives: Theory and Evidence from Ghana. Journal of Political Economy, 103(5), 903-937.

Binswanger, H. P. , and Deninger, K. (1999). The Evolution of the World Bank's land policy: Principles, experience, and future challenges. World Bank Research Observer, 14(2), 247-76.

ERES (2009).Does Land Registration Guarantee Access to Formal Capital for Investment? European Real Estate Society Digital Library -volume: Conference 2009. https://eres.architexturez.net/doc/oai-eres-id-eres2009292

Deininger, K. (2003). Land Policies for Growth and Poverty Reduction, Washington DC, World Bank.

Dorner, P., and Saliba, B. (1981). Interventions in Land Markets to benefit the Rural Poor. Discussion Paper, University of Wisconsin, Land Tenure Center, Madison, W.I.

Feder, Gershon. (1985). The Relation between Farm Size and Farm Productivity: The Role of Family Labor, Supervision, and Credit Constraints. Journal of Development Economics, 18(1),297-313.

Feder, G., and Nishio, A. (1999). The Benefits of Land Registration and Titling: Economic and Social Perspective. Land Use Polic, 15(1), 25-43.

Field, E., and Torero, M. (2004). Do Property Titles Increase Credit Access among the Urban Poor? Evidence from a Nationwide Titling Program. rwj.harvard.edu/.../Field\%20Do\%20Property\%20Titles\%20Increase\%20Credit....pdf

Fleisig, H., and De la Pena, N. (1996).Peru: How Problems in the Framework for Secured Transactions Limit Access to Credit. Working paper, Center for the Economic Analysis of Law.

Fmdqotc (2013). Pricing Supplement (Supplementary Shelf Prospectus) to the Shelf Prospectus dated $31^{\text {st }}$ December 2013. http://www.fmdqotc.com/wp-content/uploads/2015/03/Nasarawa-State-bond-FinalPricing.pdf

Fola, A. (2013). Getting a Certificate of Occupancy (C of O) in Lagos.https://www.privateproperty.com.ng/news/getting-a-certificate-of-occupancy-c-of-o-in-lagos

Henssen, J. L. G. (1990). Cadastre, Indispensable for Development : Inaugural Address : Visiting Professor of Legal Cadastre and Land Registration at the International Institute for Aerospace Survey and Earth Sciences ITC on 6 April 1990, Enschede. Enschede, ITC.

Holden, P. (1997). Collateral without Consequence: Some Causes and Effects of Financial Underdevelopment in Latin America. The Financier, 4(1),12-21.

Inter-American Development Bank (IDB) (1986). Jamaica Land Titling Project: Feasibility Report, Washington, DC.

Map of World (2017). Political Map of Nigeria. https://www.mapsofworld.com/nigeria/nigeria-political-map.html

McKechnie, L. (2005). Property Rights Reform in Peru: Why Titles do not Increase Access to Micro-credit. Journal of Development and Social Transformation, 2(1),51-60.

Migot-Adholla, S., Hazell, P., et al. (1991). Indigenous Land Rights Systems in Sub-Saharan Africa: A Constraint on Productivity? World Bank. 5: 155-175.

Mosher, A. T. (1966). Getting Agriculture Moving: Essentials for Development and Modernization. Praeger Publishers, Agricultural Development Council, New York.

NSN (2015) List of Solid Minerals in Nasarawa

Olofinji, L. (2015) A Brief of Land Ownership in ownership-in- nigeria.html/
State.http://www.nasarawastate.gov.ng/solidminerals.php

Nigeria. http://nigeriarealestatehub.com/a-brief-of-land- 
Omon-Julius, O. (2016).Delta Slashes Certificate of Occupancy Fee .https://www.thisdaylive.com/index.php/2016/04/02/delta-slashes-certificate-of-occupancy-fee/

O'Sullivan, A., and Sheffrin, S. M. (2003). Economics: Principles in Action. Upper Saddle River, New Jersey 07458: Pearson Prentice Hall. p. 29. ISBN 0-13-063085-3.

Panandikar, S.G. (1956). Banking in India. Orient Longmans, Madras.

Pender, J. L., and Kerr, J. M. (1994). The Effect of Transferable Land Rights on Credit, Land Investment and Use : Evidence from South India. Brigham Young University, Department of Economics, Provo, UT.

Sacay, O.J. (1973). Credit and Small Farmer Development in the Phillippines. Spring Review of Small Farmer Credit: Small Farmer Credit in the Phillippines, 13, pp. 1-32. US Agency for International Development, Washington, D.C.

Salas, O., Knight, F., and Saenz, C. (1970). Land Titling in Costa Rica: A Legal and Economic Survey, USAID Contract 515 -178-T. USAID and University of Costa Rica Law School, San Jose.

Satope, B. F.; Akanbi, B. (2014). Effect of Business on Economic Development in Nigeria. Journal of Business Management and Economics, 5(4),091-096.

Services.gov.ng (2016) Nasawara State. services.gov.ng/nasarawa

Stiglitz, Joseph and Andrew Weiss (1981). Credit Rationing in Markets with Imperfect Information. American Economic Review 3(71): 393-410.

Viewmynaijanaira (2015) Top 20 Lucrative Businesses in Nigeria that Make Millions of Naira. http://mynaijanaira.com/top-20-lucrative-businesses-in-nigeria-that- make-millions-of-naira/

Villamizar, M. F. (1984). IDB Financing in Land Administration Programs. Paper presented at the International Workshop on Land Tenure Administration, August 20-24, Salvador, Brazil.

Wai, U. T. (1957). Interest Rates Outside the Organized Money Markets of Under-developed Countries. IMF Staff Papers 6 (Suppl. 1), 80-142.

Wikipedia (2015) Nasarawa.https://en.wikipedia.org/wiki/Nasarawa.

Wikipedia (2016) Location of Nasarawa $\quad$ State in Nigeria https://en.wikipedia.org/wiki/Nasarawa_State\#/media/File:Nigeria_-_Nasarawa.svg

Wikipedia (2017). Nigeria. https://en.wikipedia.org/wiki/Nigeria

World Atlas (2016). Where is Nigeria. http://www.worldatlas.com/af/ng/where-is-nigeria.html

World Bank (2016).Registering Property in Nasarawa (Lafia) - Nigeria. Ww.doingbusiness.org.

\section{Copyrights}

Copyright for this article is retained by the author(s), with first publication rights granted to the journal.

This is an open-access article distributed under the terms and conditions of the Creative Commons Attribution license (http://creativecommons.org/licenses/by/4.0/) 